\title{
Contra a ditadura da escola
}

\author{
Wilmar da Rocha D’Angelis*
}

\begin{abstract}
RESUMO: Este texto, escrito em 1995, busca colocar em questão certas compreensões quase ingênuas do que seja fazer (ou tornar) uma escola indígena. Por isso é ainda atual, quando a discussão dos currículos das escolas está em pauta. O texto aponta o desafio de se conquistar uma "escola indígena" e sugere que a educação escolar indígena faria muito (e melhor) se fosse capaz de apenas duas coisas: um bom ensino de matemática e a formação efetiva de leitores.
\end{abstract}

Palavras-chave: Educação escolar indígena, currículo, conhecimento, autonomia, cultura indígena

... acho que em qualquer parte do país, quando se coloca uma escola para dentro de uma comunidade indígena, os índios não sabem para que serve uma escola: eles não conhecem a escola; não sabem quais os objetivos da escola; o que ela quer fazer lá; o que ela está tentando fazer lá. Se ela quer melhorar ou piorar, ou quer afundar ou quer acabar ou quer exterminar os índios, ninguém sabe. Mas quem colocou a escola sabe o que quer com a escola. (...) Quer dizer, eles sabem o que eles querem, mas nós, índios, não estamos sabendo desses interesses. A gente ainda tem embarcado no barco deles ...

(Bruno Ferreira, kaingang)

* Professor do Departamento de Lingüística do IEL, Unicamp, e membro do Núcleo de Cultura e Educação Indígena da ALB (Associação de Leitura do Brasil). Colabora com programas de educação escolar indígena, sobretudo com o povo kaingang. E-mail: wilmar@iel.unicamp.br 
Sempre me espanta o simplismo com que são tratadas questões fundamentais em educação escolar indígena. Lamentável é o império do senso comum. E, como seria de esperar, o senso comum de uns legitima o senso comum de outros (assim como quando alguém recorre a um ditado): os "assessorados" identificam o valor de suas práticas intuitivas na fala de assessores que têm, a diferenciar-se deles, uma capacidade razoavelmente superior de articulação (como se fossem "camelôs pedagógicos") ou um espaço de poder que lhes confere o direito do "discurso competente".

Às vezes, porém, são especialistas que caem na armadilha do senso comum, o que é lamentável e, ao que parece, fruto de falta de clareza política e da adoção de um certo populismo.

Vejam-se os seguintes "conselhos", bastante comuns, quando se fala de construir um currículo indígena para a escola, ou de construir uma "escola indígena":

$\mathrm{Na}$ comunidade há muitos conhecimentos agrícolas (técnicas de plantio, escolha e cuidados com sementes, tipos de solo, terra forte e fraca, época de plantio, cuidados e riscos com o clima), muito conhecimento empírico dos acidentes geográficos (rios, serras, tipos de vegetação etc.) e dos limites das terras. (Geografia)

Ciência (ou a etnociência) é todo conhecimento construído pelo povo indígena, ao longo de gerações e de séculos, acerca do seu meio, da fauna, da flora, do clima etc. (Ciências)

A tradição indígena construiu, em cada povo, técnicas ou formas próprias de contagem e de manipulação de quantidades e medidas. Todo índio um dia precisa construir um arco, medi-lo, medir uma flecha, uma casa em construção, a área de uma cobertura ou avaliar a duração de uma viagem ou expedição. Tudo isso é feito segundo padrões de conhecimento próprio. (Matemática)

Aparentemente não há nada errado com todas essas afirmações. Mas apenas aparentemente. Se elas estão sendo mobilizadas em um discurso que defende a existência de conhecimentos próprios dos povos indígenas, que devem ser respeitados da mesma forma que respeitamos os conhecimentos que, na nossa sociedade, chamamos de científicos, estão muito corretas. Mas se estão sendo postuladas - como freqüentemente o são - como indicadoras dos conteúdos a serem ministrados nas diversas disciplinas de uma escola que seja indígena, 
elas são confusas, se pretendem ser gerais, e em boa parte equivocadas para a maioria dos casos de escola em área indígena.

A questão que se coloca é: para que uma comunidade indígena quer escola? Que função a escola tem ou a comunidade está disposta a the conferir?

Tomemos um exemplo: o caso dos conhecimentos agrícolas, transcrito acima. Se o conhecimento existe - e, com certeza, há centenas de anos - em uma comunidade indígena, e antes de haver escola esse conhecimento pôde ser transmitido, reelaborado, melhorado, geração após geração, é óbvio que esse tipo de conhecimento não precisa da escola ou, dito de outro modo, que a comunidade não precisa da escola para conservar, construir e transmitir esse tipo de conhecimento. Parece, pois, que nos propomos a fugir de um preconceito (o de que o conhecimento construído pelos povos indígenas não é conhecimento) alimentando outro (o de que o conhecimento indígena será conhecimento verdadeiro se for ensinado na - ou avalizado pela - escola). A comunidade indígena tem suas formas próprias de ensinar e não está provado (nem faria sentido que alguém tentasse provar) que a escola (ou o ensino escolar) é a forma mais adequada, mais eficiente, mais segura para se garantir a continuidade e o aprofundamento de toda e qualquer forma de conhecimento.

Rebelo-me, pois, contra a ditadura da escola. Parece que vemos reacender-se pelo Brasil afora uma marcha de cunho positivista, cheia de esperança em um progresso inexorável da humanidade pela razão, cujo "templo" - a implantar-se em toda e qualquer aldeia - é a escola. ${ }^{2}$ Diz-se, no meio indigenista, que a escola é instrumento que os índios tomam para se livrar do jugo branco, como forma de luta, como meio de apoderar-se de conhecimentos e técnicas que os brancos manipulam contra eles, como forma de conquistar sua autonomia. Há um explícito discurso não-"civilizatório" nessa "cruzada escolar" (que, não por acaso, coincide com a existência de recursos oficiais, possibilidades de convênios etc.), mas que parece contradito pelo próprio caráter de "cruzada" dessa "epidemia educacional" e, sobretudo, por essa prática - fundada em um certo senso comum - de "enfiar" toda a cultura para dentro da escola.

O ponto que defendo, portanto, é que o resultado dessa prática - de transformar a cultura indígena em conteúdo de programa ou currículo escolar - não será uma escola indígena, mas uma cultura indígena ocidentalizada, deformada pela usurpação de espaços próprios da educação indígena. Defendo também que o conhecimento não é independente das formas próprias de sua construção, dos mecanismos de sua produção. Assim, 
qualquer agricultor entende que não faz o menor sentido ensinar numa sala de aula qual é o terreno mais adequado ao plantio de uma ou outra cultura (sem intenção de fazer trocadilho), a melhor forma de seleção ou conservação de sementes etc. Alguém objetaria que ao propor que se faça isso na escola, ou que a escola tome esses conhecimentos como conteúdo, não se está propondo, necessariamente, que se faça isso no espaço da sala de aula, mas que a escola, ao contrário, deve ser indígena também nisso, saindo do espaço de um prédio etc. Mesmo isso, porém, não resolve a questão de fundo que coloquei. No caso exemplificado, dos conhecimentos agrícolas, em qualquer sociedade ou comunidade de agricultores o aprendizado se faz pela observação, imitação, orientação, e mesmo por meio de conselhos e explanações, porém sempre relacionados aos momentos reais, efetivos, de uso daqueles conhecimentos. Em certo sentido, pode-se dizer que um(a) menino(a) indígena aprende a plantar como aprende a falar: em muitos aspectos ele(a) repete gestos observados, aprendidos, transmitidos silenciosamente por muitas gerações, sobre os quais não há qualquer explicação ou necessidade dela. ${ }^{3}$

No fundo, o que está em jogo também aqui é a questão da autonomia - possível ou impossível - das escolas indígenas. ${ }^{4}$ Por que não se admite que uma escola, em uma comunidade indígena, não tem nada a dizer sobre certas questões, tem muito pouco a dizer sobre outras, e deveria preocupar-se em fazer bem aquilo para o que foi desejada ou solicitada por aquela comunidade? É comum e recorrente a afirmação de que as comunidades indígenas pedem escola porque querem saber ler, escrever e fazer conta "pra deixar de ser enganadas pelos brancos" e coisas semelhantes. Mas será que as escolas em áreas indígenas estão realmente empenhadas, por um lado, em um bom ensino de matemática e, por outro, em formar efetivamente leitores (e não meros decifradores de sílabas, num arremedo de processo que se costuma chamar de "alfabetização") $?^{5}$ Atuassem as escolas indígenas de maneira intensa e eficiente nessas duas áreas, resolvendo as questões fundamentais que estão sempre presentes nas solicitações das comunidades indígenas, e tudo o mais seria dispensável.

Alguns gostariam de interpretar minha atitude, então, como a defesa de uma escola "capenga" para os povos indígenas. Nada mais contrário ao que disse ou quero dizer. Em primeiro lugar, lembro sempre, e mais uma vez, que não há uma situação única e, provavelmente, sequer uma situação padrão das escolas indígenas no país. Realidades totalmente distintas, em razão de culturas distintas, de diferentes histórias e, mesmo, da diferenciação no processo de ocupação e desenvolvimento 
das várias regiões do país (e ainda de regiões diferenciadas dentro de um mesmo estado), tudo isso faz com que uma escola indígena possa ser, nos casos extremos, muito distinta até mesmo de outra escola indígena a menos de $20 \mathrm{~km}$ de distância.

Por outro lado, mesmo com essa diferenciação bastante grande, arrisco-me a dizer que, em sua maioria, as escolas indígenas estão em grande descompasso com as necessidades das comunidades em que se encontram e que, em todos esses casos, sem exceção, substituir uma escola ruim com um vasto currículo por uma boa escola que ensine só e simplesmente a ler (e não silabar), a escrever e bem contar é a melhor forma de contribuir efetivamente para a autonomia das comunidades indígenas. E nos casos em que se pode ou deve investir em uma escola "completa", ${ }^{6}$ nas quais um currículo "amplo" tem sua importância dadas as funções efetivamente atribuídas à escola naquelas circunstâncias, o conteúdo das disciplinas não deve conflitar com as formas próprias e particulares de educação no sentido que já apontei, ou seja, não deve tomar espaços que pertencem às formas próprias da cultura indígena, "escolarizando" conteúdos que não dizem respeito à escola. No fundo, o que parece ocorrer é que muitos educadores confundem na prática o que não confundem no discurso: igualam escola a educação, querendo fazer, então, uma "escola indígena" que seja igual a uma "educação indígena". ${ }^{7}$

É preciso reconhecer que, sendo a escola uma instituição não-indígena, surgida em contextos de sociedades radicalmente distintas das sociedades indígenas, criar hoje a "escola indígena" é ainda um desafio. Ele vem sendo assumido por muita gente em muitos lugares, o que tem gerado muitas experiências importantíssimas que, aos poucos, vão permitindo um certo acúmulo de conhecimento nessa área bastante nova, mas em nenhum caso pode-se afirmar com segurança que já se construiu uma "escola indígena". O que temos conseguido são escolas mais, ou menos, indianizadas (por vezes, mais indigenizadas do que indianizadas). Na esmagadora maioria dos casos são tentativas de "tradução" da escola para contexto indígena.

A criação de algo que tenha características de ensino escolar (ou seja, um ensino formalizado, num espaço ritualizado de produção - em geral, de mera reprodução - de conhecimento) em uma sociedade indígena que mantém suas formas e seus processos próprios de educação, de forma que esse ensino formalizado seja apenas um elemento que se toma no que tenha de útil, mas que se digere e se tritura e se refaz, num processo "antropofágico", como fizemos com o football em 
tempos idos (antes do "futebol de resultados" típico do Brasil anos 80 e 90), isso é algo ao que ainda não assistimos em nenhuma sociedade indígena no Brasil. Impossível? Provavelmente sim, pelo menos por ora, quando no Brasil talvez existam, em média, um assessor (missionário, educador, professor, lingüista, antropólogo, indigenista) para cada 70 ou 80 índios. ${ }^{8}$ Nesse contexto, há muito pouco espaço - e, freqüentemente, muito dinheiro - para permitir aos povos indígenas qualquer arremedo de verdadeira autonomia. ${ }^{9}$ Retorno, pois, ao tema da tutela sobre a escola e sobre o movimento indígena, que já tenho abordado. Quem não queira ser agente dessa dominação viverá sempre a tensão das escolhas, a autocrítica permanente, a dúvida jamais resolvida dos limites de sua intervenção. Os inconseqüentes dormirão sempre mais tranqüilos. Afinal, se os objetivos dos índios coincidirem com os seus, ótimo, caso contrário, não era essa, para eles, a preocupação primordial: para muitos, índios (ou educação indígena) são mero pretexto, que poderá ser substituído por reprodução controlada de borboletas, estudo dos riscos para a camada de ozônio, contabilização de assassinatos de menores, mapeamento do DNA ameríndio ou contagem de centímetros quadrados publicados sobre a Amazônia em jornais de circulação nacional. A questão indígena é refém, infelizmente, de um mercado de serviços, em que muita gente séria obriga-se a negociar o emprego, e freqüentemente é levada a escolhas entre a manutenção deste ou a tomada de posições que rompem com interesses de burocracias indigenistas, encasteladas em todas as instituições.

Concordando com a afirmação do professor Bruno, que coloquei na abertura deste artigo, também tenho afirmado - como fiz no I Encontro de Educação Escolar Indígena da América Latina (Dourados, UFMS, março 1998) - que o balanço do atual momento histórico aponta que, com nossa amizade sincera, mas às vezes ingênua, estamos embarcando os povos indígenas na nossa canoa furada da escola compulsória que inviabiliza, a longo prazo, a educação indígena, e fará dela "uma mera lembrança nostálgica, à espera de outro genial Florestan Fernandes para descrevê-la", como já afirmei em outro lugar.

\section{Notas}

1. "Obstáculos à autonomia das escolas indígenas". Exposição feita no I Encontro de Educação Indígena do 10 Cole, Congresso de Leitura do Brasil. In: D’Angelis e Veiga 1997, p. 214. 
2. Isso é o que está dito, com todas as letras, na proposta de Plano Nacional de Educação elaborada pelo MEC: "Universalizar, em dez anos, a oferta de programas educacionais equivalentes, pelo menos, às quatro primeiras séries do ensino fundamental às comunidades indígenas, respeitando seus modos de vida (...)" etc.

3. Embora pareça, não estou assumindo uma teoria behaviorista de "aprendizagem da fala"; os termos "observação", "repetição" etc. querem de fato referir-se à experiência do(a) menino(a) na comunidade agricultora, safra após safra. A comparação é feita apenas para enfatizar o quanto se aprende (e mesmo na língua materna há aprendizado, além do nível inicial de aquisição) sem se tomar consciência e sem se ocupar explicitamente, em momentos estanques, de um aprendizado.

4. Veja-se, em D'Angelis e Veiga 1997 (obra citada), os capítulos com os debates: "Limites e possibilidades de autonomia de escolas indígenas" (pp. 139168) e "Escola indígena: Um caso particular de escola?" (pp. 169-201).

5. Estou apenas incorporando, aqui, essa questão fundamental da formação de leitores indígenas, que não foi originalmente levantada por mim, mas por colegas lingüistas com vasta experiência em educação escolar indígena, particularmente Tereza Machado Maher e Marilda Cavalcanti (Unicamp).

6. "Completa" está sendo usada aqui não com sentido de "mais plena" do que as outras que defendi, mas no sentido das normas burocráticas do sistema de ensino oficial brasileiro, inclusive com seus "regimentos", "boletins de freqüência" etc.

7. Para muitos a afirmação parecerá óbvia e sua reiteração desnecessária. Parece-me, no entanto, que ainda é útil relembrá-la, porque em muitas experiências atuais a confusão conceitual e prática permanece. Melià, que já chamara a atenção para isso em Educação indígena e alfabetização (1979), retoma-a em texto mais recente: "Os termos ou elementos que é necessário aclarar de início são precisamente educação, escola e alfabetização. Tais conceitos, que deveriam ficar bem delimitados em qualquer programa educativo, necessitam de definições ainda mais acabadas quando se trata de educação escolar indígena. (...) Quando nos propomos estabelecer uma escola dentro de uma comunidade indígena, baseamo-nos geralmente no pressuposto de que essa sociedade, essa 'tribo', precisa de educação e precisa de educação porque não está alfabetizada; e que para alfabetizar-se precisa da escola" (Melià 1995, pp. 149-150; tradução minha).

8. Essa é uma estimativa conservadora, que trabalha com um número de aproximadamente três mil agentes indigenistas para um total aproximado de 250 mil índios no Brasil. A soma total deveria incluir: todos os funcionários da Funai, todos os professores de redes estaduais e municipais de ensino em áreas indígenas, todos os missionários e agentes religiosos de todas as denominações (dos membros do Cimi aos da Missão Novas Tribos, passando pelos lingüistas do SIL e do Alem), todos os indigenistas/antropólogos e de- 
mais agentes das chamadas ONGs (CPIs, CTI, Anaís, ISA, lamá, NEls e outras), todos os antropólogos, lingüistas e educadores que, não ligados a ONGs ou à Funai, atuam em projetos de educação escolar indígena etc.

9. Vale anotar, de passagem, outro trecho do depoimento do professor kaingang, Bruno Ferreira, no $10^{\circ}$ Cole: "Outro problema que enfrentamos para efetivar uma educação e uma autonomia das escolas indígenas e dos povos indígenas é que as ONGs têm as comunidades indígenas na mão. Elas têm poder de manipulação muito forte em cima dos povos indígenas. Aí eu me pergunto como essas ONGs, que dizem que trabalham para os índios, falam de autonomia indígena, autonomia dos povos indígenas. (...) Eles conhecem todo o nosso lado fraco, nosso ponto forte e nosso ponto fraco. Quer dizer, eles estão estrategicamente montados. Isso, graças à colaboração de antropólogos, lingüistas, historiadores”. In: D’Angelis e Veiga 1997, pp. 215-216.

\title{
Against the dictatorship at school
}

\begin{abstract}
This text, written in 1995, tries to bring to issue certain comprehension almost naive about what is making (or turning) a school, indigenous. That's why it's still up-to-date, when the schools are discussing the curriculum. The text shows the challenge to conquest an indigenous school" and suggests that indigenous school education would do much (and better) if it were able of only two things: a good Mathematics teaching and the effective formation of readers.
\end{abstract}

Bibliografia

D'ANGELIS, Wilmar R. e VEIGA, Juracilda (orgs.). Leitura e escrita em escolas indígenas. Campinas: ALB/Mercado de Letras, 1997, pp. 212-220.

FERNANDES, Florestan. "Notas sobre a educação na sociedade tupinambá". In: FERNANDES, F. A investigação etnológica no Brasil e outros ensaios. Petrópolis: Vozes, 1975, pp. 33-83.

FERREIRA, Bruno. "Obstáculos à autonomia das escolas indígenas". In: D'ANGELIS, W.R. e VEIGA, J. (orgs.). Leitura e escrita em escolas indígenas. Campinas: ALB/Mercado de Letras, 1997, pp. 212-220.

MELIÀ, Bartomeu. Educação indígena e alfabetização. São Paulo: Loyola, 1979.

Elogio de la lengua guarani. Assunção: Cepag, 1995. 